\title{
An Examination Of Faculty Innovativeness In Relation To Inductive Teaching And The Use Of Technology
}

Donald A. Forrer, Hodges University, USA

Nancey A. Wyant, Hodges University, USA

Patricia C. Gordin, Hodges University, USA

\begin{abstract}
The conceptual framework for this research describes the processes faculty use to create an online course that meets learning outcomes while creating a positive learning experience for the online student. This involves acceptance of technology to create a course structured for inductive learning in addition to traditional deductive learning. The presence of faculty innovation is demonstrated by the design of inductive learning exercises. Innovative professors must continue to enhance the quality of their online delivery in an effort to achieve the same educational outcomes acquired in a traditional classroom. However, many professors are reluctant to embrace online delivery software and technology designed to enhance the classroom. This research identifies innovation, technology acceptance, inductive learning, and quality enhancement as measures online quality in an academic environment. The assessment instrument for this research is the Rubric for Online Competencies and Standards (ROCS) developed by Hodges University. The ROCS consist of twenty-eight quality indicators in six categories extracted from a combination of regional standards from accreditation bodies including, but not limited to: SACS, Sloan-C, and EDUCAUSE.
\end{abstract}

Keywords: Faculty Innovativeness; Technology; Inductive Learning; Distance Education; Online Course; Pedagogy; Learning Community

\section{INTRODUCTION}

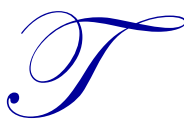

his research examines innovativeness of faculty in regards to acceptance of technology to provide inductive learning opportunities when teaching online. Today's online delivery software and supporting technology provides faculty numerous tools necessary to deliver an online course that meets the rigorous academic standards found in a traditional classroom offering. However, there is significant research indicating that faculty remains reluctant to use the necessary technology to create learning opportunities that will enhance his/her course.

It is hard to imagine any university Dean allowing a faculty member to remain on staff if they delivered a traditional classroom course offering virtually no collaboration, inductive learning, faculty lectures, interactive activities, or communication between the student and professor. Unfortunately, while the majority of online offerings maintain very high standards, research indicates that too many courses are below average. Academic institutions must assess online courses and provide professional development to eliminate substandard practices. This paper outlines an assessment process utilized by Hodges University of Naples Florida.

This research examines the literature on innovation, inductive learning, and acceptance of technology in online instruction. The analysis section of this research outlines a peer-to-peer review process conducted by Hodges University to assess how professors utilize technology to create inductive learning methods i.e., completing projects. This research is in the early stages and this paper will serve as the starting point for a detailed study on faculty innovation in regards to technology acceptance and inductive learning techniques. 
Courses evaluated in this research use the Blackboard online delivery software. Research indicates that Blackboard is one of the leading web based delivery software systems utilized by colleges and universities. Studies indicate that Blackboard significantly improves the delivery of online courses (Roberts-DeGennaro et al., 2005; Carnevale, 2006; Larkin \& Benson, 2005; Jefferies et al., 2003). Although, Blackboard provides the basic course enhancement tools, it is up to the university administration and faculty to utilize its capabilities and determine which enhancements are necessary to deliver the required learning outcomes. While Blackboard provides modules to guide students through the course, anarchy could prevail in the course if guidelines and structure are not provided by competent faculty.

\section{Conceptual Framework}

The conceptual framework for this research describes the processes faculty use to create an online course that meets program outcomes while delivering a positive learning experience for the online student. This involves acceptance of technology to create a course structured for inductive learning in addition to traditional deductive learning i.e., applying concepts by examination. The presence of faculty innovation is demonstrated by the design and execution of inductive learning exercises. The variables listed in the conceptual framework are reviewed in the literature review and analyzed through the peer-to-peer review process discussed in the analysis section of this paper.

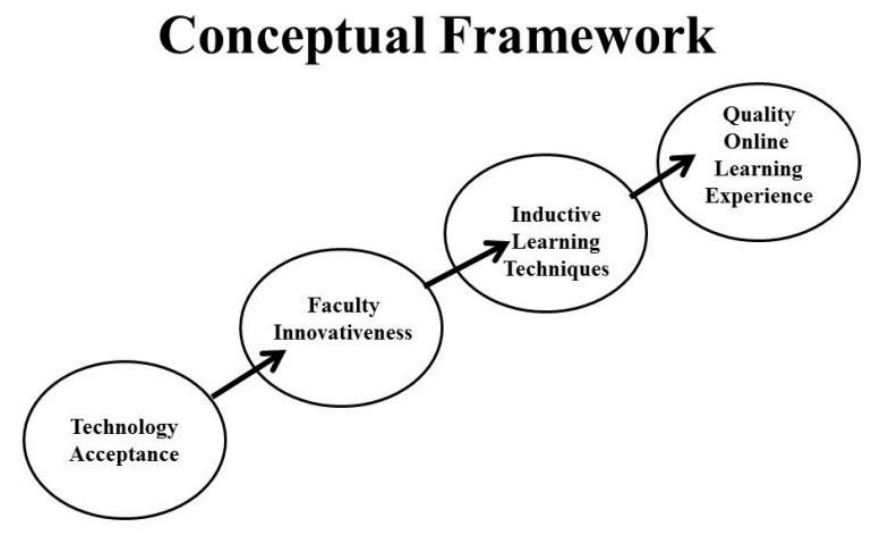

\section{Technology Acceptance}

It is difficult to implement online learning without the acceptance of new technology by institution faculty. Masrom (2007) defined technology acceptance as "an individual's psychological state with regard to his or her voluntary or intended use of a particular technology." The Technology Acceptance Model (TAM) is a tool utilized by Masrom to verify end-users acceptance of technology. According to Maslin's research there is a significant reluctance on the part of faculty to accept technology even though online instruction is a major component in most universities.

Waheed and Farooq (2010) proposed an extended TAM model to address the willingness of faculty to accept online technology. Their study determined that four factors influenced professors to accept technology designed for online learning. Their study included faculty at an online university and concluded that perceived ease of use, perceived usefulness, facilitating conditions, and computer efficacy were determining factors in faculty willingness to implement new e-learning systems. They discovered that tenure played a significant role in acceptance with faculty teaching twenty years or more displaying the most reluctance to adopt technology. Their research also revealed that professors were concerned that students would know more about the technology than they do, thus causing discomfort for the faculty member. Research by Liaw et al., (2007) indicated that training must be provided to ensure that faculty possesses the skills necessary to respond to student questions. Other research concluded that workload and time played a significant role in faculty acceptance of online technology (Tabata \& Johnsrud, 2008). 
A study by Lin et al. (2010) examined use and resistance of technology in universities. Their study included 1,022 faculty and administration from various universities. This research utilized the conceptual framework of technology and structural enactment developed by Orlikowski (2000). This framework concluded that structure was not a physical entity, but institutional knowledge activated by action on the part of staff and faculty. Wenger's community of practice is another avenue of scholarly support for this concept (Wenger et al., 2002). Once it is established that structure is not materialistic, planners can create a strategy to enhance the online classroom by implementing technological changes that enhance instruction. Lin's study determined that structure enables faculty to enhance quality in the online classroom, but can also constrain instructional efforts if the premise of structure being an institutionalized culture is not accepted.

Faculty interaction with Blackboard and any supporting technology is determined by the course strategy being augmented by human action. Faculty members must be intricately involved in every aspect in development of online courses. Acceptance of technology is critical in an academic setting as technological capabilities define the institutions ability to sustain a competitive advantage. Since most educational institutions share the same technology assets, it is imperative that a competitive advantage is gained through the method in which the technology is used.

Delivering a quality course utilizing inductive learning techniques created by innovative faculty with an emphasis on technology is a key to success. At Hodges University, emphasis is placed on the availability of assets while still maintaining academic freedom. Each course is unique and treated as such with faculty members maintaining the freedom to create a course that meets the learning outcomes required. The distance education staff at Hodges University provides a Blackboard template for continuity, training, and support assets, but otherwise allows faculty to be innovative. The peer-to-peer assessment instrument addressed in this research analyzes success and identifies professional development opportunities based on results.

\section{Faculty Innovation}

Innovation on the part of online faculty is based on the open innovation concept identified in a book by Chesbrough (2006). Open innovation is defined as "...the use of purposive inflows and outflows of knowledge to accelerate internal innovation, and expand the markets for external use of innovation, respectively" (Chesbrough et al., 2006, p. 32). This is the type of innovation required of faculty as new technology is combined with inductive learning techniques to create quality in online learning. In an academic setting, open innovation provides discoveries, findings, inventions, and knowledge. Open innovation provides the link between strategies, technology and inductive exercises that produce competencies demanded by current students. To compete in today's educational marketplace, universities cannot rely on traditional methods. Universities must engage in new idea generation by beginning in the classroom with meaningful inductive learning exercises that engage students and produce a viable product at the end of the course. This concept is also supported by educational research on "constructivism." Social Cognitive theorists such as Bandura also support the social construction of knowledge through group work and instructor interaction (Morrison et al., 2007, p. 158-159).

Eynon (2008) conducted a study of forty-one staff members at two British universities to determine the motivation issues guiding institutions utilizing information technology in the classroom. Results indicated that positive motivators included supporting existing resources, encouraging independent learning, providing additional resources to professors, and providing an experience for students. Additionally, motivational factors included in the study for not utilizing technology in the classroom included time issues, technical support, constraints with the course, roles, and structural issues. Overall, university staff encouraged the use of technology because of profits and flexibility, while faculty resisted due to various changes necessary to adapt the course environment to include technology. Faculty embracing technology cited innovation, flexibility, and enhanced teaching capabilities. The adoption of technology in the classroom depends on the level of faculty innovation combined with perceived support from university administration.

\section{Inductive Learning}

Another important variable in development of an enhanced online course is utilization of an inductive learning process. Traditional courses are more often than not taught deductively by professor's utilizing lectures, 
models, theory, and examinations while students apply the material to real-world scenarios if possible. Students are not motivated through doing, but rather by exams and possible future uses. Inductive learning techniques offer students motivation through the challenge of completing a project with material delivered in the online classroom, but requiring them to complete an applied project. Students solve a case, interpret data, or apply knowledge to realworld scenarios.

Prince and Felder (2007) define inductive learning as "Instruction that begins with a challenge for which the required knowledge has not been previously provided technically qualifies as inquiry-based learning, and the scope of the inquiry may vary from a portion of a single lecture to a major term project. In this sense, all inductive methods are variants of inquiry, differing essentially in the nature of the challenge and the type and degree of support provided by the instructor" (p. 15). Prince and Felder advocates that inquiry learning techniques or inductive learning improves academic achievement and better prepare students for real-world issues. This thought is also supported by the new Bloom's Taxonomy through creation (formerly synthesis) and evaluation (Krathwohl, 2002).

According to Prince and Felder (2007), students involved in case-based learning, problem- based learning, discovery learning, just-in-time teaching, and project-based learning through questions supported with materials and a challenge to solve a real-world problem will develop the skills required to master subject materials. Research on inductive learning supports students adopting a deeper approach to learning when this approach is used (Ramsden 2003; Norman \& Schmidt 1992). The peer-to-peer process utilized by Hodges University measures inductive learning techniques in several areas and indicates how faculty members apply these techniques through technology.

\section{Enhanced Online Classroom}

Research indicates that computer technology provides instructional technology that enhances the faculty's ability to deliver a quality course (Eynon, 2008). To this end, it is important that university administration provide the infrastructure to support faculty innovation while at the same time measure delivery to ensure faculty engagement in the use of technology. Research by Inoue and Buczynski (2011) points out that inductive learning is dependent upon instructors challenging students to be active participants in the learning process rather that accepting only what the professor provides. Therefore, faculty must be innovative in the use of technology and the process of course design to ensure students are actively engaged in learning activities.

When participating in inductive learning, students are encouraged to design their own solutions to complex problems instead of the professor providing detailed step-by-step procedures. The key elements in this practice are conjecturing, invention, and problem solving as students develop multi-strategy solutions to workplace problems (Van de Walle, 2004). Inductive learning can evolve from guided inquiry with the teacher leading to student centered learning or open inquiry with the student accepting responsibility for solution to the problem. The goal is student involvement in solving a real-world issue.

Research indicates that delivering inductive learning in an online environment requires faculty to: 1) begin with a problem that is meaningful and applicable to real-world situations, 2) allow students to apply current knowledge with new knowledge by asking open-ended questions, 3) provide guidance by placing a priority on important elements of the problem, 4) promote self-direction and collaboration by encouraging students to be creative, and 5) provide opportunities for students to connect theory to practice (Ormrod, 2003; Woolfolk, 2006). Following these steps and providing assessments that measure progress will create an inductive learning environment. Successful outcomes are dependent upon faculty innovation and use of available technology. Inoue and Buczynski (2011) contends that a stumbling block to success is when students ask an open-ended question and the faculty member is not prepared to provide guidance.

The peer-to-peer review process at Hodges University provides evaluation by fellow faculty members in an effort to continuously improve the online program. The analysis section below describes results from the FY2011 evaluation. 


\section{ANALYSIS}

As noted earlier, research by Orlikowski (2000) determined that, when measuring innovation, organizational structure was not a physical entity, but institutional knowledge activated by action on the part of staff and faculty. At Hodges University, administration officials have worked diligently to ensure courses delivered online meet university standards and enhance the institutional knowledge in regards to online learning. Knowledge enhancement is a philosophy instituted by action, expectations, and assessment. In addition to the traditional end-ofterm evaluations and faculty evaluations, Hodges University employs other methods to assess the pedagogy in the online program. Methods such as student information sheet, expectations essay, questionnaire, early term evaluation and others provides data for administrators to gauge faculty responsiveness. The main assessment instrument for measuring technology acceptance, faculty innovation, inductive learning techniques, and delivery of a quality online program is the Rubric for Online Competencies and Standards (ROCS).

It is the annual review of the ROCS evaluations that drives discussions among colleagues on the Distance Education Committee toward a discovery and adoption process. Two theories of organizational workings help to explain this process. First, the community of practice theory of social learning (Wenger, 1998) explains how professional development and collaboration play key roles in organizational learning, a primary goal of assessment. In this case, learning within a community brought about mutual understanding. Second, sense making (Weick, 1995) describes the process through which the results of assessment and self-reflection can be transformed into organizational goals. Mutual understanding, structure, and process together form the conditions in which the roles of these higher education practitioners intersect to propel distance education toward its future.

\section{Data Collection}

The ROCS assessment instrument has evolved since 2007 with significant improvement to the process each year. The ROCS consist of twenty-eight quality indicators in six categories extracted from a combination of regional standards from accreditation bodies including, but not limited to: SACS, Sloan-C, and EDUCAUSE. For the purpose of this research, we will concentrate on indicators of technology acceptance, inductive learning, and faculty innovation.

Since the inception of the ROCS assessment instrument, each online faculty member is required to submit a self-evaluation annually. Supervisors review this self-assessment and complete an evaluation of one course using the same instrument. This becomes part of the annual faculty review. Initially, this process was augmented with a university peer-to-peer review where faculty evaluated each other. To improve quality, distance education staff enacted the current version of the peer-to-peer review by selecting eighteen courses representing lower division, upper division, and graduate level offerings. A team approach was employed where faculty and distance education staff teamed together to evaluate the six categories of the ROCS. Each team was assigned one category to strengthen reliability.

Courses were randomly selected from the Fall 2011 term to compare to the same term in previous evaluations. All twenty-eight indicators of exemplary practice in an online course were evaluated on a scale of zero (Not Evident) to five (Exemplary). The combined statistical analysis coupled with historical data provided the university with a training needs assessment. Several training initiatives were implemented or improved including instructional design courses, Blackboard training, best practices, user groups, and others. At this printing, the 2012 review is underway with the hope that significant improvement will be noted.

\section{Data Analysis/Discussion}

Inter-rater reliability (simple correlation) was calculated for each of the six teams of two, focusing upon a related group of ROCS indicators in the 2011 assessment. It was expected that scores for 2011 would be slightly lower due to improved evaluation processes. There were some pleasant surprises and some training opportunities noted. Score results are shown in Tables 1-6a and correlations between team members' scores are displayed in Tables 1-6b. 
Overall, there was a strong correlation between scorers in two teams and a moderate correlation on one team, indicating that there was agreement among half of all team members on how to apply the indicators to individual online courses. 2011 score results may be an indicator of closer scrutiny from evaluators and should improve in 2012.

\section{Learner Support}

All indicators in this category were lower than in previous reviews. In fact, the average for the category for Fall 2011 was fully one point lower (on a scale of 0-5). The lowest indicator was 1. Links to library and online learning resources. This was something of a mystery, as each course contains a menu button for Library that is populated each term by library staff. However, with a correlation of .74, this team was mostly in agreement about how to apply the indicators to individual courses.

Table 1a: Four-Year Trend for Scores in Learner Support and Resources

\begin{tabular}{|c|c|l|c|c|c|c|}
\hline \multirow{2}{*}{ Category } & $\begin{array}{c}\text { ROCS } \\
\text { No. }\end{array}$ & \multicolumn{1}{|c|}{ Indicator } & $\begin{array}{c}\mathbf{2 0 0 7} \\
\text { Fall }\end{array}$ & $\begin{array}{c}\mathbf{2 0 0 8} \\
\text { Fall }\end{array}$ & $\begin{array}{c}\mathbf{2 0 1 0} \\
\text { Fall }\end{array}$ & $\begin{array}{c}\mathbf{2 0 1 1} \\
\text { Fall }\end{array}$ \\
\hline \multirow{3}{*}{ Learner } & 1 & Links to library and online learning resources & 3.7 & 3.3 & 3.7 & 2.7 \\
\cline { 2 - 8 } Support & 2 & Course and program resources and contact information & 3.3 & 3.4 & 4.3 & 2.9 \\
\cline { 2 - 8 } & 3 & Range of resources supporting course content & 3.1 & 3.7 & 3.9 & 3.1 \\
\cline { 2 - 8 } & \multicolumn{2}{|c|}{ Category Average } & 3.4 & 3.5 & 3.9 & 2.9 \\
\hline
\end{tabular}

Table 1b: Correlations between Scorers in Learner Support and Resources in Fall 2011

\begin{tabular}{|c|c|c|}
\hline \multicolumn{2}{|c|}{ Learner Support and Resources (Strong Correlation) } & \multirow{2}{*}{$\begin{array}{r}\mathbf{0 . 7 4} \\
0.60 \\
\end{array}$} \\
\hline 1 & Links to library and online learning resources & \\
\hline 2 & Course and program resources and contact information & 0.74 \\
\hline 3 & Range of resources supporting course content & 0.88 \\
\hline
\end{tabular}

Online Organization \& Design

This category shows evidence that support elements for the online program are a training opportunity. While each indicator in the category was rated lower than in previous reviews, the indicator that really stood out on the chart was 8 . ADA Accessibility. The extent of non-compliance on this indicator was a surprise to the reviewers. Corrective actions included the adoption of a set of standards for ADA compliance and plans for faculty professional development to meet those standards.

Table 2a: Four-Year Trend for Scores in Online Organization \& Design

\begin{tabular}{|l|c|l|c|c|c|c|}
\hline \multicolumn{1}{|c|}{ Category } & $\begin{array}{c}\text { ROCS } \\
\text { No. }\end{array}$ & \multicolumn{1}{|c|}{ Indicator } & $\begin{array}{c}\mathbf{2 0 0 7} \\
\text { Fall }\end{array}$ & $\begin{array}{c}\mathbf{2 0 0 8} \\
\text { Fall }\end{array}$ & $\begin{array}{c}\mathbf{2 0 1 0} \\
\text { Fall }\end{array}$ & $\begin{array}{c}\mathbf{2 0 1 1} \\
\text { Fall }\end{array}$ \\
\hline \multirow{3}{*}{ Online } & 4 & Evidence of organization and clear navigation & 4.2 & 3.9 & 4.2 & 3.9 \\
Organization & 5 & Defined role of the online environment in the syllabus & 4.3 & 4.6 & 4.0 & 3.8 \\
\& Design & 6 & Intentional page design and clarity of course information & 3.7 & 3.1 & 3.8 & 3.4 \\
& 7 & Visual and functional consistency of Blackboard pages & 4.1 & 3.4 & 3.9 & 3.1 \\
& 8 & Americans with Disabilities Act (ADA) accessibility & 3.1 & 3.7 & 3.6 & 0.7 \\
\cline { 2 - 8 } & \multicolumn{2}{|c|}{ Category Average } & 3.9 & 3.7 & 3.9 & 3.0 \\
\hline
\end{tabular}

Table 2b: Correlations between Scorers in Online Organization \& Design in Fall2011

\begin{tabular}{|l|r|r|}
\hline Online Organization and Design (No Correlation) & $\mathbf{0 . 0 0}$ \\
\hline 4 & Evidence of organization and clear navigation & -0.12 \\
\hline 5 & Defined role of the online environment in the syllabus & 0.32 \\
\hline 6 & Intentional page design and clarity of course information & -0.21 \\
\hline 7 & Visual and functional consistency of Blackboard pages & 0.02 \\
\hline 8 & Americans with Disabilities Act (ADA) accessibility & 0.07 \\
\hline
\end{tabular}

Instructional Design \& Delivery

This category speaks directly to faculty innovation and inductive learning opportunities. Research indicates that a positive attitude is present when faculty is using technology in a meaningful and relevant way (Berge 
et al., 2002). This finding is supported by prior research that indicates that technological competency is a positive motivator.

Indicators in this category evaluate how innovative faculty members employ resources to create a quality online class. There was a strong correlation between team members' scores. As Table 3a demonstrates, scores in this category fell considerably from the previous evaluation. The critical difference may again lie in the improved assessment methodology of evaluation for 2011. Results varied if evaluators used the syllabus as a reference for student outcomes versus Blackboard. As a solution, Hodges University created a syllabus database that maps program outcomes to the syllabus. This will allow for consistency in 2012 measures.

Table 3a: Four-Year Trend for Scores in Instructional Design \& Delivery

\begin{tabular}{|l|c|l|c|c|c|c|}
\hline \multicolumn{1}{|c|}{ Category } & $\begin{array}{c}\text { ROCS } \\
\text { No. }\end{array}$ & \multicolumn{1}{|c|}{ Indicator } & $\begin{array}{c}\text { 2007 } \\
\text { Fall }\end{array}$ & $\begin{array}{c}\mathbf{2 0 0 8} \\
\text { Fall }\end{array}$ & $\begin{array}{c}\mathbf{2 0 1 0} \\
\text { Fall }\end{array}$ & $\begin{array}{c}\mathbf{2 0 1 1} \\
\text { Fall }\end{array}$ \\
\hline & 9 & Interaction among student, instructor, and content & 3.4 & 3.1 & 4.2 & 2.3 \\
& 10 & Alignment of course goals with learning outcomes & 4.0 & 3.9 & 4.6 & 2.4 \\
& 11 & Integration of learning outcomes with instr. activities & 3.8 & 4.0 & 3.8 & 2.1 \\
Instructional & 12 & Multiple means of representation, action and expression, & 2.9 & 2.9 & 4.0 & 2.1 \\
Design \& & 13 & and engagement (i.e., Visual, textual, auditory, etc.) & 3.7 & 3.6 & 4.4 & 2.6 \\
Delivery & 14 & Critical thinking and problem-solving activities & 2.9 & 3.3 & 4.4 & 1.6 \\
& 15 & Academic rigor of course content and requirements & 4.1 & 3.3 & 4.2 & 2.8 \\
& 16 & Course processes identified and communicated & 3.1 & 3.4 & 4.0 & 2.1 \\
\cline { 2 - 8 } & \multicolumn{2}{|c|}{ Category Average } & 3.5 & 3.4 & 4.2 & 2.2 \\
\hline
\end{tabular}

Table 3b: Correlations between Scorers in Instructional Design \& Delivery in Fall 2011

\begin{tabular}{|c|c|c|}
\hline \multicolumn{2}{|c|}{ Instructional Design and Delivery (Strong Correlation) } & \multirow{2}{*}{$\mathbf{0 . 7 2}$} \\
\hline 9 & Interaction among student, instructor, and content & \\
\hline 10 & Alignment of course goals with learning outcomes & 0.81 \\
\hline 11 & Integration of learning outcomes with instructional activities & 0.81 \\
\hline 12 & $\begin{array}{l}\text { Multiple means of representation, action and expression, and } \\
\text { engagement (i.e., Visual, textual, auditory, etc.) }\end{array}$ & 0.68 \\
\hline 13 & Critical thinking and problem-solving activities & 0.49 \\
\hline 14 & HU's 5 educational outcomes are integrated and measurable & 0.41 \\
\hline 15 & Academic rigor of course content and requirements & 0.86 \\
\hline 16 & Course processes identified and communicated & 0.83 \\
\hline
\end{tabular}

Assessment \& Evaluation

Table $4 \mathrm{~b}$ indicates a weak correlation and provides opportunities for team improvement. The lowest indicator, 21. Opportunities for self-assessment, reflection, and peer feedback is critical for the development of critical thinking and metacognition. This is an area that should show great improvement in 2012 due to university emphasis on the assessment process through both process improvement and professional development.

Table 4a: Four-Year Trend for Scores in Assessment and Evaluation of SLO's

\begin{tabular}{|c|c|c|c|c|c|c|}
\hline Category & $\begin{array}{l}\text { ROCS } \\
\text { No. }\end{array}$ & Indicator & $\begin{array}{l}2007 \\
\text { Fall } \\
\end{array}$ & $\begin{array}{c}2008 \\
\text { Fall } \\
\end{array}$ & $\begin{array}{c}2010 \\
\text { Fall } \\
\end{array}$ & $\begin{array}{l}2010 \\
\text { Fall }\end{array}$ \\
\hline \multirow{6}{*}{$\begin{array}{l}\text { Assessment \& } \\
\text { Evaluation of } \\
\text { SLOs }\end{array}$} & 17 & $\begin{array}{l}\text { Activities to assess student readiness for course } \\
\text { content }\end{array}$ & 3.3 & 4.0 & 3.0 & 3.3 \\
\hline & 18 & $\begin{array}{l}\text { Alignment of learning objectives/outcomes with } \\
\text { instruction and assessment }\end{array}$ & 3.9 & 3.4 & 4.4 & 4.1 \\
\hline & 19 & $\begin{array}{l}\text { Multiple assessment strategies to measure } \\
\text { knowledge, skills, attitudes }\end{array}$ & 3.9 & 3.9 & 4.2 & 3.7 \\
\hline & 20 & $\begin{array}{l}\text { Timely feedback on student performance throughout } \\
\text { the course }\end{array}$ & 3.3 & 3.0 & 4.1 & 3.5 \\
\hline & 21 & $\begin{array}{l}\text { Opportunities for self-assessment, reflection, and } \\
\text { peer feedback }\end{array}$ & 2.6 & 3.6 & 3.3 & 2.8 \\
\hline & \multicolumn{2}{|r|}{ Category Average } & 3.4 & 3.6 & 3.8 & 3.5 \\
\hline
\end{tabular}


Table 4b: Correlations between Scorers in Assessment \& Evaluation in Fall 2011

\begin{tabular}{|c|c|c|}
\hline \multicolumn{2}{|c|}{ Assessment and Evaluation (Weak Correlation) } & \multirow{2}{*}{$\begin{array}{r}\mathbf{0 . 1 6} \\
-0.26 \\
\end{array}$} \\
\hline 17 & Activities to assess student readiness for course content & \\
\hline 18 & $\begin{array}{l}\text { Alignment of learning objectives/outcomes with instruction and } \\
\text { assessment }\end{array}$ & 0.07 \\
\hline 19 & $\begin{array}{l}\text { Multiple assessment strategies to measure knowledge, skills, } \\
\text { attitudes }\end{array}$ & 0.36 \\
\hline 20 & Timely feedback on student performance throughout the course & 0.25 \\
\hline 21 & Opportunities for self-assessment, reflection, and peer feedback & 0.40 \\
\hline
\end{tabular}

Innovative Teaching with Technology

As indicated in Table 5b, team scores for this category were moderately correlated. There is no doubt that faculty roles have been redefined by technology. Online courses can closely mirror traditional classroom delivery methods if the professor is innovative in his/her use of available technology (Schuster \& Finkelstein, 2006). According to Tabata and Johnsrud (2008), quality instruction provided by innovative faculty is the only way any distance education initiative is successful.

This review is not unlike reviews of previous years. The lowest two indicators were 22. Communication and learning through the use of Blackboard features and 23. Active learning and engagement facilitated by technology tools. Recent professional development has included Blackboard Collaborate, an upgrade of Wimba Classroom. The category should show improvement in 2012 measures.

Table 5a: Four-Year Trend for Scores in Innovative Teaching with Technology

\begin{tabular}{|c|c|c|c|c|c|c|}
\hline Category & $\begin{array}{l}\text { ROCS } \\
\text { No. }\end{array}$ & Indicator & $\begin{array}{l}2007 \\
\text { Fall }\end{array}$ & $\begin{array}{l}2008 \\
\text { Fall }\end{array}$ & $\begin{array}{l}2010 \\
\text { Fall }\end{array}$ & $\begin{array}{l}2011 \\
\text { Fall }\end{array}$ \\
\hline \multirow{5}{*}{$\begin{array}{l}\text { Innovative } \\
\text { Teaching with } \\
\text { Technology }\end{array}$} & 22 & $\begin{array}{l}\text { Communication and learning through use of } \\
\text { Blackboard features }\end{array}$ & 2.8 & 2.9 & 3.3 & 3.0 \\
\hline & 23 & $\begin{array}{l}\text { Active learning and engagement facilitated by } \\
\text { technology tools }\end{array}$ & 2.4 & 2.6 & 3.3 & 3.0 \\
\hline & 24 & $\begin{array}{l}\text { Relevance and variety of interactive activities (i.e., } \\
\text { Web 2.0) }\end{array}$ & 2.1 & 2.7 & 3.1 & 3.1 \\
\hline & 25 & $\begin{array}{l}\text { Use of Internet to engage students in the learning } \\
\text { process }\end{array}$ & 2.9 & 3.1 & 3.5 & 3.4 \\
\hline & & Category Average & 2.6 & 2.8 & 3.3 & 3.1 \\
\hline
\end{tabular}

Table 5b: Correlations between Scorers in Innovative Teaching with Technology in Fall 2011

\begin{tabular}{|l|r|r|}
\hline \multicolumn{2}{|l|}{ Innovative Teaching w/Technology (Moderate Correlation) } & $\mathbf{0 . 5 6}$ \\
\hline 22 & Communication and learning through use of Blackboard features & 0.56 \\
\hline 23 & Active learning and engagement facilitated by technology tools & 0.20 \\
\hline 24 & Relevance and variety of interactive activities (i.e., Web 2.0) & 0.78 \\
\hline 25 & Use of Internet to engage students in the learning process & 0.71 \\
\hline
\end{tabular}

Faculty Use of Feedback

Team scores in this category were weakly correlated but could be a function of the ability for evaluators to determine if feedback is being utilized. This is a training opportunity and could be as simple as improved documentation. The indicator that scored the lowest, 27. Opportunities for student feedback on Blackboard course delivery was improved with direction to create a discussion board entry for students to discuss issues with the professor. With greater emphasis upon the definition of each indicator, reliability should improve in 2012 measures. 
Table 6a: Four-Year Trend for Scores in Faculty Use of Student Feedback

\begin{tabular}{|l|c|l|c|c|c|c|}
\hline Category & No. & \multicolumn{1}{|c|}{ Indicator } & $\begin{array}{c}\mathbf{2 0 0 7} \\
\text { Fall }\end{array}$ & $\begin{array}{c}\mathbf{2 0 0 8} \\
\text { Fall }\end{array}$ & $\begin{array}{c}\mathbf{2 0 1 0} \\
\text { Fall }\end{array}$ & $\begin{array}{c}\mathbf{2 0 1 1} \\
\text { Fall }\end{array}$ \\
\hline & 26 & $\begin{array}{l}\text { Opportunities for student feedback on course content (e.g., } \\
\text { learning outcomes, activities, and assessments) }\end{array}$ & 3.1 & 3.3 & 3.2 & 3.6 \\
$\begin{array}{l}\text { Faculty } \\
\text { Use of } \\
\begin{array}{l}\text { Student } \\
\text { Feedback }\end{array}\end{array}$ & 27 & $\begin{array}{l}\text { Opportunities for student feedback on Blackboard course } \\
\text { delivery } \\
\text { Use of formal and informal feedback to guide instruction/ } \\
\text { Course Sequencing }\end{array}$ & 2.4 & 3.7 & 2.9 & 3.1 \\
\cline { 2 - 7 } & Category Average & 2.8 & 3.4 & 3.2 & 3.2 \\
\hline
\end{tabular}

Table 6b: Correlations between Scorers in Faculty Use of Student Feedback in Fall 2011

\begin{tabular}{|c|c|c|}
\hline \multicolumn{2}{|r|}{ Use of Student Feedback (Weak Correlation) } & 0.29 \\
\hline 26 & Opportunities for student feedback on course content & 0.40 \\
\hline 27 & Opportunities for student feedback on Blackboard course delivery & 0.15 \\
\hline 28 & Opportunities for student feedback on content sequencing & 0.32 \\
\hline
\end{tabular}

Improvements to evaluation process produced several notable results in 2011 and should improve significantly in 2012. Efforts by distance education staff produced some agreement on the application of quality indicators, resulting in consistent assessment by half of all evaluators. Improvements in team processes in the 2012 will improve the reliability of the assessment process. An increased granularity was a benefit of the new process, in which 18 courses at the lower division, upper division, and graduate levels were evaluated. The new process employed by Hodges University solidified faculty as a solid learning community thus validating the conceptual concept of Orlikowski (2000) where structure is an attitude as opposed to physical. Additionally, the process closed the loop on reliability issues from previous evaluations and provided documentation for future training initiatives.

\section{CONCLUSION}

As noted earlier, this research is the baseline to evaluation of faculty innovation, technology acceptance, and use of inductive learning techniques to improve delivery of online course. The literature and analysis provided demonstrates the need for further research. Future initiatives include a more detailed review of inductive learning techniques supported by innovation and technology.

According to research, faculty requires a strong support system to motivate them into actively participating in online learning. Universities that provide support through training, workshops, assessment, encouragement, and other forms produce significantly improved online courses (Chizman \& Williams, 2001; Lee \& Busch, 2005). This is further supported by research. A study by Tabata and Johnsrud (2008), revealed that there are eleven significant variables significant to faculty embracing online instruction. These include: 1) importance of using software, 2) importance of using e-resources, 3) skillful at using technology, 4) technology being important in professional work, 5) faculty possessing technical skills, 6) quality of the online course being perceived as high as a traditional classroom course, 7) distance education being compatible to work style, 8) faculty self-image is enhanced by technological innovations, 9) distance education courses perceived as difficult, 10) the ability to see results of online delivery, and 11) the ability to try out online teaching before committing.

It is noted throughout this research that institutional support is critical to the success of online instruction. In addition to the eleven variables listed above that indicate the probability of faculty members embracing online instruction, Tabata and Johnsrud (2008) found five variables that indicate when there is a decreased likelihood of faculty involvement in online instruction. These include the perception of faculty that: 1) resources are not available to support online teaching, 2) the institution does not value distance education, 3) participation in online instruction is not voluntary, 4) faculty cannot share online instruction results with other faculty, and 5) the advantages of teaching online do not outweigh the disadvantages. This research and results of the peer-to-peer evaluation underscore the importance of the support team at Hodges University.

Hodges University is unique in its approach to distance education as faculty is afforded academic freedom similar to the traditional classroom. The administration is committed to supporting online instruction while 
maintaining academic integrity through a detailed assessment program. Hodges University faculty are encouraged to professionally develop and supported through instructional design courses at the local and national levels. Technology tools such as Blackboard, Collaborate, WIMBA, Tegrity, Snagit, Jing, Voice podcasts and numerous others are readily available with training. With the exception of the basic university template for continuity, faculty members are free to be innovative and creative. The peer-to-peer review process assesses usage and provides both best practices and training opportunities.

Future research will include a statistical analysis of technology acceptance, faculty innovation, and inductive learning techniques. This research will also be followed with a comparison to results from the 2012 study when it is available. Enhanced assessment policies and creation of a team approach provide an opportunity to compare 2011 and 2012 with the understanding that they were both evaluated with the same standards. This is an ongoing process that will serve to continuously improve online courses at Hodges University.

\section{AUTHOR INFORMATION}

Donald C. Forrer has a Doctorate in Business Administration and serves as a Professor in the MBA/MPA program at Hodges University (formerly International College) of Naples, Florida. Additionally, Don is the CEO/President of Cybernetics Concepts, a management consulting team specializing in utility economics. He served as a management professor at Troy University, Strayer University, Embry-Riddle University, Central Michigan University \& International College. He has lectured on management topics in Taiwan, Japan, Guam, and throughout the United States. E-mail: dforrer@hodges.edu (Corresponding author)

Nancey A. Wyant is the Dean of the Johnson School of Business, Hodges University, USA. E-mail: nwyant@hodges.edu

Patricia C. Gordin has a Ph.D. in Curriculum \& Instruction and MBA from USF and M.Ed. in Educational Technology from FGCU. She is Program Director of and Associate Professor in the Masters in Professional Studies Program at Hodges University. She taught leadership, educational technology, and curriculum \& instruction courses for Florida Gulf Coast University 2007-2010. She has taught Education and Interdisciplinary courses at the graduate and undergraduate levels for Hodges University since January 2009. In previous work as a senior administrator, she provided guidance and professional development to all levels of Edison State College faculty, staff, and administration on planning, accreditation, and assessment procedures, supervised institutional research, and partnered with faculty on professional development initiatives. As an Information Technology professional for almost a decade before that, she designed and developed software and training at companies such as General Electric. E-mail: pgordin@hodges.edu

\section{REFERENCES}

1. Berge, T., Muilenburg, L., \& Haneghan, J. (2002). Barriers to distance education and training: Survey results. Quarterly Review of Distance Education, 3(4), 409-419.

2. Carnevale, D. (2006). Online. Chronicle of Higher Education, 52(24), A37.

3. Chesbrough, H. (2006). Open business models: How to thrive in the new innovation landscape. Cambridge, MA: Harvard Business School Publishing.

4. Chesbrough, H., West, J., \& Vanhaverbeke, W. (2006). Open innovation: Researching a new paradigm. Oxford: Oxford University Press.

5. Chizmar, J., \& Williams, D. (2001). What do faculty want? Educause Quarterly, 24, 18-24.

6. Distance Education. (2011). Hodges University. Report on the peer-to-peer review.

7. Distance Education. (2012). Hodges University. Presentation: Rocking eLearning with a score card named "ROCS".

8. Eynon, R. (2008). The use of the world wide web in learning and teaching in higher education: Reality and rhetoric. Innovations In Education \& Teaching International, 45(1), 15-23. doi:10.1080/14703290701757401 
9. Inoue, N., \& Buczynski, S. (2011). You asked open-ended questions, now what? Understanding the nature of stumbling blocks in teaching inquiry lessons. Mathmatics Educator, 20(2), 10-23. Retrieved from ERIC database (EJ923721).

10. Jeffries, P., Grodzinsky, F., \& Griffin J. (2003). Advantages and problems in using information communication technologies to support the teaching of a multi-institutional computer ethics course. Journal of Educational Media, 28, 191-202.

11. Krathwohl, D. R. (2002). A revision of Bloom's Taxonomy: An overview. Theory Into Practice, 41(4), 212-218. DOI:10.1207/s15430421tip4104_2

12. Larkin, T., \& Belson, S. (2005). Blackboard technologies: A vehicle to promote student motivation and learning in physics. Journal of STEM Education, 6, 14-27.

13. Lee, J., \& Busch, P. (2005). Facts related to instructors' willingness to participate in distance education. Journal of Educational Research, 99(2), 109-115.

14. Liaw, S., Huang, S., \& Chen, G. (2007). Surveying instructor and learner attitudes toward e-learning. Computers and Education, 49, 1066-1080.

15. Lin, C., Singer, R., \& Ha, L. (2010). Why university members use and resist technology? A structure Enactment perspective. Journal of Computing in Higher education, 22, 38-59. Doi:10.1007/s12528-0109028-1

16. Masrom, M. (2007). Technology Acceptance Model and e-learning. Proceedings. $12^{\text {th }}$ International Conference on Education.

17. Morrison, G. R., Ross, S. M., \& Kemp, J. E. (2007). Designing effective instruction (5th ed.). Hoboken, NJ: John Wiley \& Sons.

18. Norman, G., \& Schmidt, H. (1992). The psychological basis of problem-based learning: A review of the evidence. Academic Medicine,67(9), 557-65.

19. Orlikowski, W. (2000). Using technology and constituting structures: A practice lens for studying technology in organizations. Organizational Science, 11, 404-428.

20. Ormrod, J. (2003). Educational Psychology: Developing learners (5 ${ }^{\text {th }}$ ed.).Upper Saddle River, NJ: Merrill.

21. Prince, M., \& Felder, R. (2007, March/April). The many faces of inductive teaching and learning. Journal of College Science Teaching, 36(5), 14-20. Retrieved from http://mate.calpoly.edu/media/files/Prince_Felder.pdf

22. Ramsden, P. (2003). Learning to teach in higher education (2 ${ }^{\text {nd }}$ ed.). London: Taylor and Francis.

23. Roberts-DeGennaro, M., Brown C., Min, J., \& Siegel, M. (2005). Using an online support site to extend the learning to a graduate field practicum in the United States. Social Work Education, 24, 327-342.

24. Schuster, J., \& Finkelstein, M., (2006). The academic faculty: The restructuring of academic work and careers. Baltimore Maryland: The John Hopkins University Press.

25. Tabata, L., \& Johnsrud, L. (2008). The impact of faculty attitudes toward technology, distance education, and innovation. Research in Higher Education, 49, 625-646.

26. Van de Walle, J. (2004). Elementary and middle school mathematics: Teaching developmentally. Boston MA: Pearson.

27. Waheed, M., \& Farooq, A. (2010). Teacher's intention to accept online education: Extended TAM Model. Interdisciplinary Journal of Contemporary Research in Business, 2(5), 330-344.

28. Weick, K. E. (1995). Sensemaking in organizations. Thousand Oaks, CA: Sage Publications.

29. Wenger, E. (1998). Communities of practice: Learning, meaning, and identity. New York, NY: Cambridge University Press.

30. Wenger, E., McDermott, R., \& Snyder W. (2002). Cultivating communities of practice: A guide to managing knowledge. Cambridge MA: Harvard Business School Press.

31. Woolfolk, A. (2006). Educational Psychology (10 ${ }^{\text {th }}$ Ed.). Boston MA: Allyn \& Bacon. 


\section{APPENDIX A}

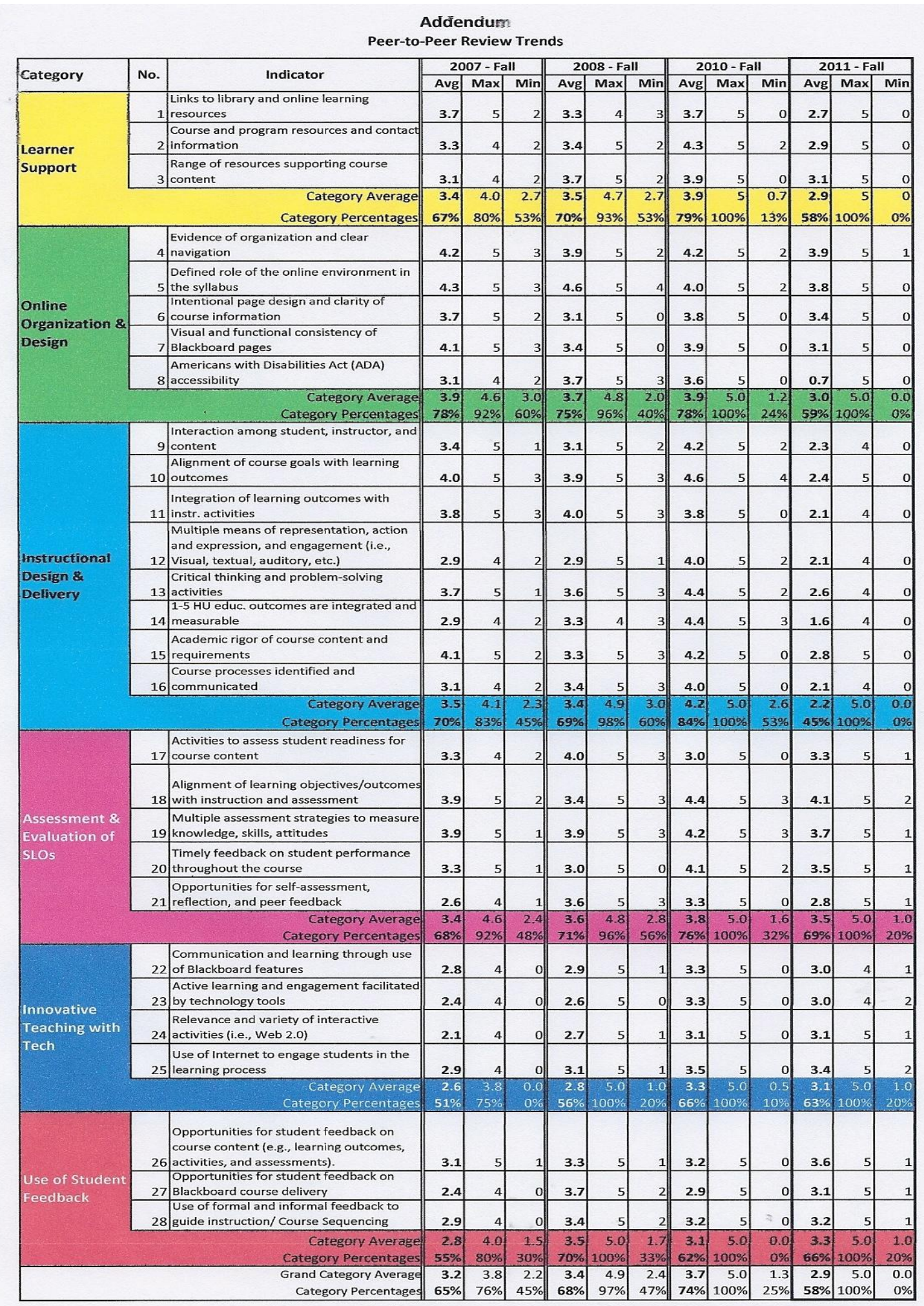

Source: Distance Education. (2011). Hodges University. Report on the peer-to-peer review. 